\section{LEVERAGING PROCESS DATA FROM BPM CLOUD-BASED WORKFLOWS}

\author{
Deasún Ó Conchúir ${ }^{1}$, Lazar Dražetaa, \\ ${ }^{1}$ Scatterwork Gmbh, \\ 8593 Kesswil, Switzerland \\ ${ }^{2}$ Singidunum University, \\ 32 Danijelova St., Belgrade, Serbia
}

\begin{abstract}
:
This paper shares the experience of a virtual team of knowledge workers which coordinates its repetitive production work across 12 time zones using cloud-based workflows.

A sample of process data and the utility that can be obtained from it are discussed, and recommendations are provided for the management of virtual teams using cloud-based workflows.

In addition, possible directions for future research relating to virtual knowledge work teams using cloud workflows are suggested. Some references to related experience for further reading are also given.
\end{abstract}

\section{Key words:}

work, workflow, time, process, cloud-based.

\section{BACKGROUND}

As the nature of work changes, labour requirements also change. External forces that shape the global economy facilitate the shift in contemporary market value. S\&P 500 companies have diverged significantly since 1975 from their book value in favour of intangible asset value, currently reaching $84 \%$ of their true market value (Ocean Tomo, 2015). Consequently, today's "knowledge workers" differ greatly from the traditional profile, being primarily information-based with intangible results of work process (Nickols, 2012) while having a high degree of flexibility regarding tenure, hours and contractual terms (Rudman, 2002).

Knowledge workers are used to working alone based on their own competence. However, in to- day's global economy, it is a costly luxury to withhold status information except at reporting milestones. By using workflows to share and manage status information, the work capacity, speed and quality of manufacturing and administrative processes can be optimised.

Workflows have been used in business environments well before cloud computing existed. For example, BPMN (Business Process Model and Notation) dates back to 2004 (White, 2006). The combination of workflows with cloud computing (a term coined in 2007) is more recent and was seen in 2008 as a possible future development (Wang et al., 2008). By using the cloud as their infrastructure, virtual teams can benefit from many features including cost efficiency, scalability, flexibility, agility etc. (Carroll et al., 2011). 
Literature related to virtual teams provides a number of definitions stating major attributes within its functional context. Amongst the variety of definitions, it is widely accepted that: "we define virtual teams as groups of geographically, organizationally and/or time dispersed workers brought together by information technologies to accomplish one or more organization tasks" (Powel et al., 2004). In addition, modern organizations are staffed by an ever growing number of knowledge workers, who are also the most expensive labour and critical to realizing the business strategies of the organization (GSA Enterprise Transformation, 2011).

In an industrial era, communications were far less pervasive and immediate than today. This meant that workers, whether manual or knowledge-based did their work independently from colleagues at other locations. When a particular item of work was finished, it was sent to the colleagues, who received it after some time, and only then they started their own value-added work, e.g. "Flawed coordination among teams, systems, and data incompatibility, and complex approval processes are common" (Ming et al., 2005).

By treating the information sharing as an integral part of work, rather than an unrecorded item of information, the work capacity, speed and quality of business processes can be improved. Hence, virtual teams epitomize a growing response to the need for accelerating time-to-market as well as providing cost-effective solutions to ever-growing organizational problems (Ebrahim et al., 2009).

\section{PROCESSES AND WORKFLOWS}

A process is a sequence of steps whose implementation can be clearly defined and documented. This means that it is carried out in the same way each time, unless the process itself is adjusted. The concept of workflows builds on this and includes complete processes, which are used to drive an item of work from start to finish (BPM Center of Excellence, 2009).
Factory production lines have been defining processes and documenting them as the basis for control, process improvement and training for many decades. Usually, the status of the work is visible or tracked, to support teamwork coordination. This stems from the fact that a manual work process, regardless of the level of competence required, consists of converting materials from one form to another in order to create a tangible outcome (Nickols, 2012).

Knowledge workers, however, do not always share the detailed status of their work, with the exception of some process-oriented environments. The advent of global virtual teams means that work status information must be shared to optimize the capacity of knowledge working processes. Furthermore, the diversity of contemporary work generations enhances this issue, particularly when considering the nature of tools in current use (Dimensional Research, 2015) and the key interpersonal competencies for the knowledge economy such as team work and the ability to collaborate (OECD, 2001).

\section{BUSINESS PROCESS MANAGEMENT}

Business Process Management (BPM) is concerned with processes and workflows. In some industries, such as pharmaceutical manufacture, this approach is very thoroughly implemented in SOPs (standard operating procedures). BPM workflows are similar to typical flowcharts, with the addition of "swimlanes" which convey visually who (or which department) carries out a particular task, in addition to showing the sequence of tasks, e.g. processing insurance claims (BearBuy, 2012). Once a workflow has been prototyped and tested, it can be launched by the manager whenever the corresponding business process needs to be carried out.

By the end of the 20th century, BPM was typically managed using either paper documents or a dedicated workflow engine and database, accessed via a client on the user's computer. This access was expanded to include browsers, particularly 
for those responsible for carrying out the productive work according to the workflows. It is argued that BPM is a means that provides more effective approach to organizational change while being the second fastest growing integrative software market segment that attracts a lot of attention worldwide (Ryan, 2009). With service-oriented architecture based on cloud computing technology, the BPM can be progressively adjusted to suit ever-changing business requirements for the knowledge economy (Fang \& Yin, 2010).

Some applications include a workflow engine and also manage the implementation of the workflow cycle, by telling the user what step to carry out and then messaging the next person in the chain by email. This lends itself immediately to cloudworkflows for use globally.

A standard notation called BPMN (Business Process Model and Notation) is maintained by the Object Management Group, updated as BPMN Version 2.0 in 2011 (Object Management Group, 2011). A standard notation simplifies sharing workflows between processes and organisations. There is also scope for greater efficiencies by developing reusable BPMN models (Lu et al., 2010)

\section{CLOUD WORKFLOW TOOLS}

The availability of workflow tools which work entirely in the cloud, both for workflow modelling and management of repeated work cycles using the workflows, has opened the door to entirely new opportunities (Wu et al., 2013)

The Software as a service (SAAS) nature of many of these tools permits globally distributed virtual teams to do the following:

- Manage workflow design and usage.

- Use the workflows to control the detailed value-add work of the organisation.

- Introduce workflow practice at much lower cost levels than would be required by a server based approach. This extends the scope to many processes where it would not be viable by other methods, e.g. bedside data collection in the health service, using mobile phone apps for data entry.

- Accumulate and use workflow data.

The ability to use globally distributed virtual teams brings the usual well known benefits of virtual teams including:

- Abundant choice of experts, their location, time zones, languages, cultures, availability and costs. This can result in a much better match between the requirements and selection of experts.

- Management does not need to arrange office accommodation for virtual team members. This reduces costs compared with colocation and can also accelerate kick-off.

\section{SAMPLE PROCESS DATA FROM A CLOUD-BASED WORKFLOW ENVIRONMENT}

To illustrate the type of data available from a cloud-based workflow and how it can be interpreted, the publication cycle at Scatterwork GmbH is portrayed. This consulting company, where one of the authors works, trains online for Project Management and Team Building, as well and provides Could BPM support. The publication consists of production of a weekly video, which is also published as a blog and incorporated in a newsletter mailing.

The work is carried out by a virtual team who have never met each other and are spread out over approximately 12 time zones (Eastern USA - Europe - India) - that is half way around the world. It is driven by a cloud-based workflow using the KissFlow WfMS (Wikipedia, 2016), a cloud based automation software for Google Apps developed by OrangeScape (Ha, 2012), which is triggered once per week.

The weekly workflow is in turn triggered by a monthly workflow, which initiates work up to two months in advance, so that several cycles can 
be managed concurrently. Summary data is presented from operations over a four month period from December 2015 to March 2016, following approximately eight months of process prototyping, commissioning and stabilisation. This process was ported and revised from an earlier system using a different cloud workflow application, for which about two years' experience had been accumulated.

The reported process comprises 73 steps, implemented by a team which possesses has business, marketing, IT and English Language skills.

\section{WORKFLOW REPORTS FROM KISSFLOW}

\section{Blog \& Newsletter}

This is simply an extract of the task database filtered to show only active process cycles ("items") and sorted by date. This enables the users to see how many cycles are open and their status.

\section{App Metrics}

A (KissFlow) "App" captures the description of a workflow, so the frequency of its use reflects the level of on-the-ground business activity. For example, by opening one workflow cycle for each order in factory, information becomes available about the current status of each order in the production cycle (Image 1).
This report shows how many "items" (cycles) were started in a given month and whether they have been completed. For example, in February, four cycles were started, of which three were still in progress, and one was completed.

This is as expected, because the weekly publication is rolled forward monthly, usually by four weekly cycles (but this depends on how long the month is). None of the items opened in March had been completed at the time of the report, when eight cycles were still open: one from January, three from February and four from March.

\section{Task Report}

The task report lists every process step (of which there are 73 for the reported workflow) and captures the minimum, average and maximum completion time in hours for each task over all "items" (=cycles). It also reports the number of cycle data collected for each step. This may differ from the total number of cycles as some operations are conditional and not always carried out.

There is also a feature where the deadline for each task can be set, e.g. for use where completion times must meet some requirement, such as a contract condition. Data is also collected to show how many tasks overran the deadline or required clarification by the task operator.

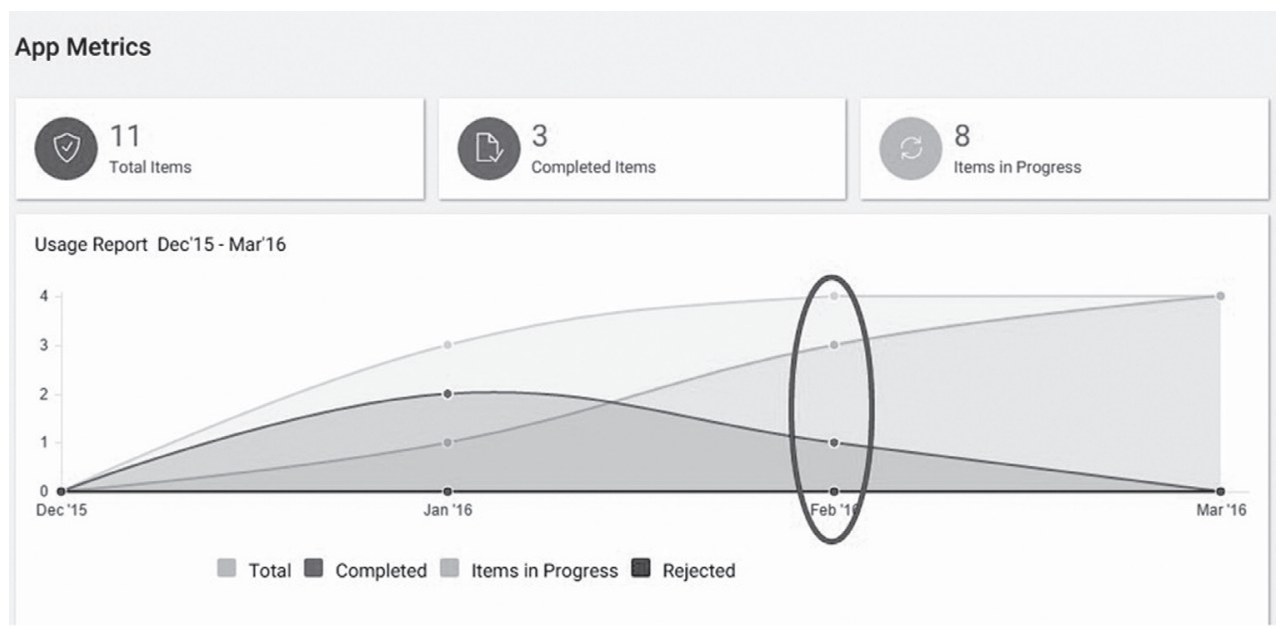


In this study, this functionality has not been utilised.

Depending on the availability of the task operator when a task notification is sent, task implementation time may vary based on the sum:

Task completion time $=$ time zone synchronisation delay + wait time + implementation time

For this workflow, implementation times are usually of the order of a few minutes, so if the completion time is significantly longer than expected allowing for time zone delays, this can signal that:

- there is a workflow fault

- the operator is not sure what to do, e.g. due to insufficient clarity or training

- the operator is not available, e.g. due to absence that has not been managed.

Examination of the data according to the average duration (or "task completion time") reveals 5 groupings or data clusters:
- Clusters 1 \& 2 represent tasks implemented on time (58\% of all tasks)

- Cluster 3 shows tasks where there is an implementation delay due to time zones (19\% of all tasks).

- Clusters $4 \& 5$ indicate workflow issues of varying severity ( $23 \%$ of all tasks).

In summary, there is considerable scope for improvement of task completion time, and efforts should be invested in 11 tasks where the average delay is over 120 hours.

\section{CONCLUSIONS AND RECOMMENDATIONS}

Our research demonstrates that it is possible to work across multiple time zones using cloud workflows. However, in order to be successful, the management needs to obtain relevant data to

\begin{tabular}{|c|c|c|c|c|c|}
\hline $\begin{array}{l}\text { Cluster } \\
\text { (hrs) }\end{array}$ & $\begin{array}{c}\text { Average } \\
\text { Duration } \\
\text { (hrs) }\end{array}$ & $\begin{array}{c}\sigma \\
(\mathrm{S} . \mathrm{D} .)\end{array}$ & $\begin{array}{l}\text { No. of } \\
\text { data } \\
\text { items }\end{array}$ & $\begin{array}{l}\text { Summary } \\
\text { Situation }\end{array}$ & Interpretation \\
\hline$<1$ & 0.04 & 0.05 & 38 & No issue. & $\begin{array}{l}\text { Small tasks that are carried out in minutes } \\
\text { without any great difficulty. }\end{array}$ \\
\hline $1-5$ & 1.75 & 0.96 & 4 & $\begin{array}{l}\text { Task flow } \\
\text { passes from one } \\
\text { operator to the } \\
\text { next one. }\end{array}$ & $\begin{array}{l}\text { Small tasks that are carried out in minutes, } \\
\text { where there may be some waiting time be- } \\
\text { cause the operator is typically working on } \\
\text { something else when the notification for this } \\
\text { work is delivered by the preceding task. }\end{array}$ \\
\hline $6-24$ & 17.7 & 7.29 & 14 & $\begin{array}{l}\text { Time zone } \\
\text { delay between } \\
\text { workflow steps. }\end{array}$ & $\begin{array}{l}\text { Tasks where the preceding task is carried out } \\
\text { in another time zone. This may result in the } \\
\text { task being implemented the next calendar day. }\end{array}$ \\
\hline $25-120$ & 63.3 & 19.4 & 6 & $\begin{array}{l}\text { Significant } \\
\text { delays. }\end{array}$ & $\begin{array}{l}\text { These tasks are: } \\
\text { - either being slowed down by some diff- } \\
\text { culty which should be investigated. } \\
\text { - or the work capacity is inadequate. This } \\
\text { is typical for management involvement in } \\
\text { the workflow. This could be avoided by } \\
\text { workflow redesign, delegation, supported } \\
\text { by training. }\end{array}$ \\
\hline$>120$ & 288 & 277 & 11 & $\begin{array}{l}\text { Serious } \\
\text { problems. }\end{array}$ & $\begin{array}{l}\text { The long delays indicate some serious prob- } \\
\text { lem, which should be investigated in depth. }\end{array}$ \\
\hline
\end{tabular}


identify and address problem areas for action with pinpoint accuracy.

Contemporary technology provides a "Virtual Teamwork Environment" that makes it easier for employees to work from home (or any remote location, such as an office) while significantly reducing workforce operating expenses. Although contemporary technologies seem to evolve quicker than people (The Economist Intelligence Unit Ltd, 2009), it is not by chance that the number of telecommuters in the USA alone has increased by $800 \%$ in the past five years and will keep growing (Black, 2014).

As with all quality efforts, the benefit should be compared with the payback before an implementation decision is taken. Since the cloud implementation of BPM, e-mail notifications and simple graphical interface for process design cost much less than traditional BPMN implementations, the potential use of cloud workflows is constantly increasing (Chen \& Ranjan, 2010).

Based on the experience reported herein, the benefits of using cloud-based BPM workflows include inter alia:

\section{RECOMMENDATIONS FOR VIRTUAL TEAM WORK}

Based on experience, it is necessary to focus on the participants themselves and the dynamics of the virtual team, in addition to processes and tools. This is particularly visible when a task is considerably delayed, because inaction is usually a big contributing factor.

Because personal engagement and collaboration can be very low where there is no pre-existing strong reason for working together, it is recommended wherever possible to work initially with a core team with some significant shared interest e.g.:

- Most or all of the team already know each other from previous shared work, events etc., particularly if it involved face-to-face meetings;

- All of them work for the same company, so thay can be "instructed" to work together;

- They all share a passionate interest and join an existing strong program which aligns with their personal or career interests.

Features

Benefits

- Processes are captured and added to the organization's know-how capital.

- The capture of business processes requires both subthe workflows) and a process expert (e.g. consultant) working together.

- Generates objective data, both of the process throughputs and bottlenecks.

- Processes can be standardized and optimized continually. ject matter experts (e.g. in the company which uses

- Knowledge Management is now a required element in ISO 9001 (ISO 9001:2015).

- The process of documentation identifies improvements which can be implemented immediately, even if workflows are not used.

- Optimisation of the workflows across time zones can be targeted to obtain the biggest benefit.

- All business departments using a particular workflow benefit from improvements, bringing everybody up to "best practice" instead of bringing them down to a "lowest common denominator".

- New application areas open up.

- Automation of the messaging between operators of sequential tasks, using email. Operators are presented with instructions for the next task.

The enforcement of detailed processes takes less effort than it would be necessary to implement using document-based BPM. This also reduces training and organizational overhead.

- Process users can be at any location with network connectivity, even across time zones and continents globally.
- Improved efficiency, cycle times and work capacity arising from better selection of personnel. 
If these conditions are not met, then the initiation should include specific, scheduled, online managed team building activities.

The authors experienced more success by working with remote companies, rather than homebased individuals. This supports a local build up of know-how and reduces service interruptions, e.g. due to illness and holidays.

As the experience in this domain increases, it would also be useful to carry out an up-to-date literature search.

\section{SUGGESTED DEVELOPMENT AREAS}

In combination with the Internet of Things (IoT), the viability of application in many domains could be usefully evaluated, e.g.

- Healthcare

- SME (Small and Medium Enterprises)

- Public Administration

- Agriculture etc.

The authors recommend identification of further real-world situations where the payback for cloud-based workflows would seem particularly to merit an evaluation, in order to implement and gain experience with BPM in Cloud-Based Workflows. For example, it includes the partitioning of BPM implementations between on-premises installations and cloud to match the business priorities regarding privacy, security, legal constraints and control (Duipmans et al., 2012).

\section{REFERENCES}

BearBuy. (2012). Insurance Workflow Process. Retrieved June 05, 2016, from http://supplychain.berkeley. edu/sites/default/files/Map101-InsuranceProcessPOSTEDfinal-6-15-2012.pdf

Black, J. (2014). Collaborating in the Cloud: Connecting Your Virtual team. Retrieved June 05, 2016, from https://www.salesforce.com/blog/2014/08/collaborating-cloud-connecting-your-virtual-team-gp.html

BPM Center of Excellence. (2009). BPM CoE Glossary. Retrieved June 05, 2016, from https://www.ftb. ca.gov/aboutFTB/Projects/ITSP/BPM_Glossary.pdf
Carroll, M., van der Merwe, A., \& Kotzé, P. (2011). Secure Cloud Computing: Benefits, Risks and Controls. Retrieved June 05, 2016, from http://citeseerx.ist.psu. edu/viewdoc/download?doi=10.1.1.232.2868\&rep= rep1\&type=pdf. doi:10.1.1.232.2868\&

Chen, J., \& Ranjan, R. (2010). Special issue: Practice and experience, Second international workshop on workflow management in service and cloud computing. Concurrency and Computation, 25(13), 1813-1815. doi:10.1002/cpe.2994

Dimensional Research. (2015). Collaboration trends and technology: A survey of knowledge workers. Retrieved June 05, 2016, from https://www.alfresco.com/sites/ www.alfresco.com/files/dimesional-research-collabsurvey-findings-report-082415.pdf

Duipmans, E.F., Ferreira Pires, L., \& Bonino da Silva Santos, L.O. (2012). Towards a BPM Cloud Architecture with Data and Activity Distribution. Retrieved June 05, 2016, from http://doc.utwente. nl/84253/1/06406222.pdf

Ebrahim, N., Shamsuddin, A., \& Zahari, T. (2009). Virtual teams: A literature review. Australian Journal of Basic and Applied Sciences, 3(3), 2653-2669.

Fang, Z., \& Yin, C. (2010). BPM Architecture Design Based on Cloud Computing. Intelligent Information Management, 2(5), 329-333. doi:10.4236/ iim.2010.25039.

GSA Enterprise Transformation. (2011). Knowledge Worker Productivity: Challenges, Issues, Solutions. Retrieved June 05, 2016, from http://www.gsa.gov/ graphics/admin/KnowledgeWorkerProductivity_Final6811.pdf

Ha, A. (2012). OrangeScape Launches Kissflow, A Workflow-Builder For Google Apps. Retrieved June 05, 2016, from http://techcrunch.com/2012/06/27/ orangescape-kissflow-launch/

International Organization for Standardization. (2015). ISO 9001:2015. Retrieved June 05, 2016, from http://www.iso.org/iso/home/store/catalogue_ics/ catalogue_detail_ics.htm?csnumber $=6208$

Lu, Y., Cai, H., \& Jiang, L. (2010). Construction of BPMN-based Business Process Model Base. International Journal of Intelligent Information Processing, 1(2), 32-38. doi:10.4156/ijiip.vol1. issue2.3

Ming, X.G., Yan, J.Q., Lu, W.F., \& Ma, D.Z. (2005). Technology Solutions for Collaborative Product Lifecycle Management - Status Review and Future Trend. Concurrent Engineering, 13(4), 311-319. doi:10.1177/1063293X05060135 
Nickols, F. (2012). The Shift from Manual Work to Knowledge Work. Retrieved June 05, 2016, from http://www.nickols.us/shift_to_KW.htm

Object Management Group (2011). Documents Associated With Business Process Model And Notation (BPMN) Version 2.0. Retrieved June 05, 2016, from http://www.omg.org/spec/BPMN/2.0/

Ocean Tomo. (2015). Components of SeP 500 Market Value. Retrieved June 05, 2016, from_http://www.oceantomo.com/blog/2015/03-05-ocean-tomo-2015-intangible-asset-market-value/

OECD. (2001). Competencies for the Knowledge Economy. Chapter 4: 99-118. Retrieved June 05, 2016, from http://www.oecd.org/innovation/research/1842070. pdf

Powel, A., Piccoli, G., \& Ives, B. (2004). Virtual Teams: a Review of Current Literature and Directions for Future Research. The ACM SIGMIS Database, 35(1), 6-36. doi:10.1145/968464.968467

Rudman, R.S. (2002). Human resources management in New Zealand. Auckland, NZ: Prentice Hall.

Ryan, K. (2009). A Computer Scientist's Introductory Guide to Business Process Management (BPM). Crossroads, 15(4), 11-18. doi:10.1145/1558897.1558901
The Economist Intelligence Unit Ltd. (2009). Managing Virtual Teams: Taking a More Strategic Approach. Retrieved June 05, 2016, from http://graphics.eiu. com/upload/eb/NEC_Managing_virtual_teams_ WEB.pdf

Wang, L., von Laszewski, G., M Kunze, M., Tao, J. (2008). Cloud computing: A Perspective study. Retrieved June 05, 2016, from http://scholarworks.rit.edu/ cgi/viewcontent. .cgi?article $=1748 \&$ context $=$ other

White, S.A. (2006). Introduction to BPMN. Retrieved June 05, 2016, from http://www.omg.org/news/meetings/workshops/soa-bpm-mda-2006/00-T4_White. pdf

Wikipedia. (2016). Workflow Management System (WfMS). Retrieved June 05, 2016, from https://en.wikipedia.org/ wiki/Workflow_management_system

Wu, Z., Liu, X., Ni, Z. Yuan, D., \& Yang, Y. (2013). A market-oriented hierarchical scheduling strategy in cloud workflow systems. The Journal of Supercomputing, 63(1), 256-293. doi:10.1007/s11227-011-0578-4

\section{KORIŠĆENJE PROCESNIH PODATAKA NA OSNOVU BPM SISTEMA ZASNOVANIH NA “KLAUD” TEHNOLOGIJI}

\section{Rezime:}

U radu se prikazuje iskustvo virtuelnog tima radnika znanja koji koordinira repetitivnom proizvodnjom u 12 vremenskih zona korišćenjem poslovnih tokova zasnovanih na "klaud" tehnologiji.

Autori analiziraju uzorak procesnih podataka i vrednost koji ti podaci mogu doneti, i nude preporuke za menadžment virtuelnih timova koji koriste poslovne tokove zasnovane na "klaud" tehnologiji.

Pored toga, ukazuje se na moguće pravce za dalje istraživanje vezano za virtuelne timove korišćenjem "klaud" tehnologije. Date su reference i izvori za dalje čitanje i obrađivanje pomenute teme.

\author{
Ključne reči: \\ $\mathrm{rad}$, \\ tok rada/posla, \\ vreme, \\ proces, \\ "klaud" tehnologija.
}

Received: August 31, 2016

Correction: September 08, 2016

Accepted: September 12, 2016 